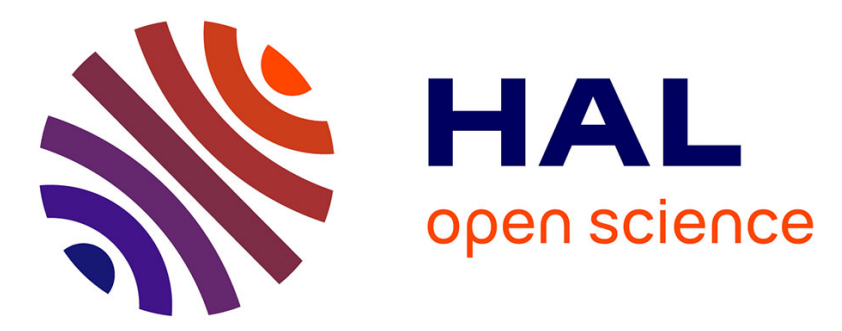

\title{
A new tool for induced spawning: The use of $17 \alpha$-hydroxy-20 $\beta$-dihydroprogesterone to spawn carp at low temperature
}

Bernard Jalabert, Bernard Breton, E. Brzuska, Alexis Fostier, J. Wieniawski

\section{- To cite this version:}

Bernard Jalabert, Bernard Breton, E. Brzuska, Alexis Fostier, J. Wieniawski. A new tool for induced spawning: The use of $17 \alpha$-hydroxy-20 $\beta$-dihydroprogesterone to spawn carp at low temperature. Aquaculture, 1977, 10 (4), pp.353-364. 10.1016/0044-8486(77)90126-0 . hal-01608771

\section{HAL Id: hal-01608771 https://hal.science/hal-01608771}

Submitted on 2 Jun 2020

HAL is a multi-disciplinary open access archive for the deposit and dissemination of scientific research documents, whether they are published or not. The documents may come from teaching and research institutions in France or abroad, or from public or private research centers.
L'archive ouverte pluridisciplinaire HAL, est destinée au dépôt et à la diffusion de documents scientifiques de niveau recherche, publiés ou non, émanant des établissements d'enseignement et de recherche français ou étrangers, des laboratoires publics ou privés.

\section{다(1)(2)}

Distributed under a Creative Commons Attribution - ShareAlikel 4.0 International 


\title{
A NEW TOOL FOR INDUCED SPAWNING: THE USE OF $17 \alpha$-HYDROXY- 20 $\beta$-DIHYDROPROGESTERONE TO SPAWN CARP AT LOW TEMPERA- TURE
}

\author{
B. JALABERT*, B. BRETON*, E. BRZUSKA**, A. FOSTIER* and J. WIENIAWSKI*** \\ *I.N.R.A., Laboratoire de Physiologie des Poissons, 78350 Jouy-en-Josas (France) \\ **Akademia Rolnicza, Instytut Zoologü Stosowanej, Al. Mickiewicza 24/28, 30059 \\ Kraków (Poland) \\ ***Instytut Rybactwa Środladowego, Zaklad Gospodarki Stawowej, Zabieniec k/ \\ Warszawy, 05500 Piaseczno (Poland)
}

(Received 10 December 1976)

\begin{abstract}
Jalabert, B., Breton, B., Brzuska, E., Fostier, A. and Wieniawski, J., 1977. A new tool for induced spawning: the use of $17 \alpha$-hydroxy-20 $\beta$-dihydroprogesterone to spawn carp at low temperature. Aquaculture, 10:353-364.

The efficiency of different hormonal treatments to induce ovulation of carp at low temperatures $\left(13-15^{\circ} \mathrm{C}\right)$ was tested. "Priming" with a low dose $(0.6 \mathrm{mg} / \mathrm{kg})$ of carp pituitary extract was found necessary for a subsequent successful treatment with $17 \alpha$ hydroxy-20 $\beta$-dihydroprogesterone $(17 \alpha-20 \beta \mathrm{P})(2 \mathrm{mg} / \mathrm{kg}) 1$ day later. The eggs produced by this method showed satisfactory fertilization $(75-96 \%)$ and hatching success $(70 \%)$.

On the other hand, normal hypophysation $(5.4 \mathrm{mg} / \mathrm{kg}$ ) following priming resulted only in partial ovulation and oocyte resorption at this temperature.

Priming was shown to increase the gonadotropin level in plasma from about 2 to 35 $\mathrm{ng} / \mathrm{ml}$ and to induce germinal vesicle migration toward the periphery of oocytes. Neither $17 \alpha-20 \beta \mathrm{P}$ nor desoxycorticosterone alone or in association gave any positive result in the absence of a preliminary priming.
\end{abstract}

\section{INTRODUCTION}

Since the first experiments by Houssay (1931), injection of pituitary hormones, or hypophysation, has been extensively used to spawn a great number of fish species artificially.

This method is routinely used and well documented for common carp Cyprinus carpio (Meske et al., 1968) as well as chinese carps (Vinogradov, 1966). However, some difficulties are associated with the current practice: the quality of injected pituitaries (carp pituitaries) is not constant, depending on the time and method of collection, on the age of donor fish and the way the pituitaries are preserved, which makes it difficult to choose the correct dose for a successful treatment; the precise criteria for assessment of 
the stage of gonadal development of spawners suitable for successful hypophysation have been lacking; hypophysation must be performed at high temperature $\left(20^{\circ} \mathrm{C}\right.$ or more), which in most continental European countries involves the use of heated water during the treatment, and also during an acclimation period, to ensure results in the event of an unexpected fall in external temperatures.

Numerous papers (reviewed by Jalabert, 1976) show that in fish, as in amphibians (Schuetz, 1974), the action of gonadotropic hormones from the pituitary on final oocyte maturation is mediated through steroid hormones. In trout, $17 \alpha$-hydroxy-20 -dihydroprogesterone $(17 \alpha-20 \beta \mathrm{P})$ appears as the most likely natural mediator of oocyte maturation (Jalabert, 1976). It is the most efficient steroid tested for in vitro oocyte maturation in trout (Fostier. et al., 1973) and also in northern pike and goldfish, a cyprinid fish closely related to carp, (Jalabert, 1976). Moreover, it was shown to induce maturation and ovulation when administered in vivo to trout. with oocytes in which the germinal vesicle was subperipheral (Jalabert et al., 1976).

A crude preparation $(\simeq 70 \%)$ of $17 \alpha-20 \beta$ P can easily be prepared from $17 \alpha$-hydroxyprogesterone which is available cheaply. It seemed justifiable to use such a crude preparation in field conditions in order to improve the hypophysation method in carp.

\section{MATERIAL AND METHODS}

The experiments were conducted in Poland at the Fish Culture Department of the Inland Fisheries Institute at Zabieniec. The fish (female carp, 5 years old, weighing $2.5-5 \mathrm{~kg}$ ) were reared in brooder ponds and transferred into concrete storage tanks where water temperature was approximately $2{ }^{\circ} \mathrm{C}$ lower than in the pond (Fig. 1 ; transfer $\mathrm{tI}$ for experiment 1 ; transfer tII for experiment 2). Before experimental handling (blood and ovarian sampling, injections) the fish were anaesthetized in MS-222 (Sandoz).

\section{Injected material}

Injections were made intraperitoneally; the dose of injected products was calculated in order to inject the same volume of physiological saline: $1 \mathrm{ml} / \mathrm{kg}$.

The carp pituitary extract (C.P.E.) was a crude preparation made as follows: an acetone-dried carp pituitary powder was suspended in saline $(6 \mathrm{mg} /$ $\mathrm{ml}$ in $8 \% 0 \mathrm{NaCl}$ ) and homogenized with five to ten strokes in a glass-teflon homogenizer, then frozen and thawed before use.

The $17 \alpha-20 \beta$ P ( 4 pregnen- $17 \alpha, 20 \beta$ diol-3 one) was prepared from $17 \alpha-$ hydroxyprogesterone by selective reduction of the 20-ketone groups with sodium borohydride in methanol-dimethylformamide (Norymberski and Woods, 1955; Smith et al., 1962). The product of this reaction was used after only one crystallization in methanol-water $(1: 1)$ (crude preparation (C.P.) $17 \alpha-20 \beta$ P containing approximately $30 \%$ of $17 \alpha$-hydroxyprogest- 


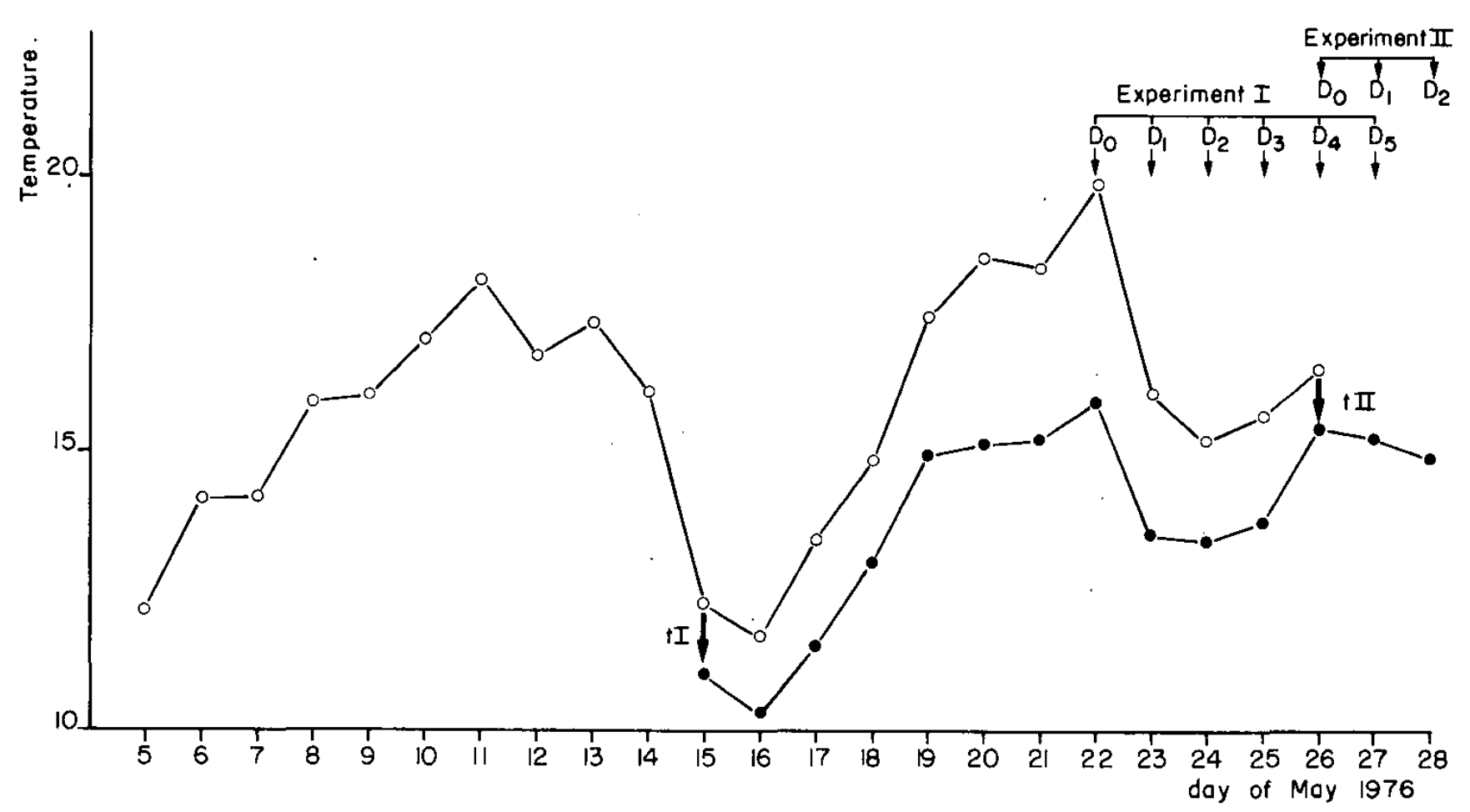

Fig. 1. Evolution of daily temperature at Zabieniec station during May 1976 in rearing ponds $(\circ-\circ)$ and in experimental tanks $(\bullet-\bullet)$. tI, transfer of fish for experiment 1 ; tII, transfer of fish for experiment 2.

erone and over-reduced derivatives) or after purification by silica-gel thinlayer chromatography. in a benzene-acetone system $8: 2$ (pure preparation (P.P.) $17 \alpha-20 \beta$ P).

The 11 desoxycorticosterone (D.O.C.) was purchased from Roussel.

Prior to injection, steroids were first dissolved in pure ethanol as a stock solution, then precipitated as a suspension in physiological saline just before injection ( $20 \%$ ethanol in the injected product).

\section{Gonadotropin determination in blood}

Blood samples of $0.5 \mathrm{ml}$ were taken from a caudal vessel by puncture in the tail, in 1-ml syringes previously rinsed with an heparine solution (700 IU/ $\mathrm{ml}$ ). The plasma obtained after centrifugation was kept frozen for subsequent determination of carp gonadotropin level (c-GtH) by the radio-immunoassay system described by Breton et al. (1972).

\section{Determination of oocyte stage}

During the experiments, most of the fish were submitted every day to an ovarian biopsy using the method described by Bieniarz and Epler (1976). At each biopsy, follicles were fixed in Serra's fixative and cleared in turpentine oil according to the method described by Brzuska and Bieniarz (1977) in order to make the germinal vesicle visible and to determine the precise stage. Stage 1: nucleus at the centre of the oocyte; 
TABLE I

Effect of different treatments on carp ovulation at low temperature

\begin{tabular}{|c|c|c|c|c|c|c|c|c|}
\hline \multirow{2}{*}{$\begin{array}{l}\text { Lot } \\
\text { number }\end{array}$} & \multirow{2}{*}{$\begin{array}{l}\text { Number } \\
\text { of fish }\end{array}$} & \multirow{2}{*}{\multicolumn{2}{|c|}{ Treatment on day 0}} & \multirow{2}{*}{\multicolumn{2}{|c|}{ Treatment on day 1}} & \multicolumn{3}{|c|}{ Number of fish with ovulated* oocytes } \\
\hline & & & & & & On day 2 & On day 3 & On day 4 \\
\hline 1 & 10 & Priming, C.P.E. & $0.6 \mathrm{mg} / \mathrm{kg}$ & \multirow{3}{*}{ Hypophysation, C.P.E. } & \multirow{3}{*}{$5.4 \mathrm{mg} / \mathrm{kg}$} & 0 & 6 part. & 7 part. \\
\hline 2 & 10 & P.P. $17 \alpha-20 \beta$ P & $1 \mathrm{mg} / \mathrm{kg}$ & & & 0 & 0 & 0 \\
\hline 3 & $8+2 * *$ & C.P. $17 \alpha-20 \beta \mathrm{P}$ & $2 \mathrm{mg} / \mathrm{kg}$ & & & 0 & 0 & 0 \\
\hline 4 & 10 & Priming, C.P.E. & $0.6 \mathrm{mg} / \mathrm{kg}$ & \multirow{2}{*}{ C.P. $17 \alpha-20 \beta \mathbf{P}$} & & \multirow{2}{*}{$\begin{array}{l}7 \text { norm. } \\
0\end{array}$} & \multirow{2}{*}{$\begin{array}{l}7 \mathrm{sp} . \\
0\end{array}$} & \multirow{2}{*}{$\begin{array}{l}7 \mathrm{sp} . \\
0\end{array}$} \\
\hline 5 & 7 & $\begin{array}{l}\text { C.P. } 17 \alpha-20 \beta \text { P } \\
\text { D.O.C. }\end{array}$ & $\begin{array}{l}2 \mathrm{mg} / \mathrm{kg}+ \\
1 \mathrm{mg} / \mathrm{kg}\end{array}$ & & & & & \\
\hline 6 & 6 & \multicolumn{2}{|c|}{ D.O.C. $1 \mathrm{mg} / \mathrm{kg}$} & \multirow{2}{*}{\multicolumn{2}{|c|}{ Physiological saline }} & 0 & 0 & 0 \\
\hline 7 & 7 & Control, physiol & ogical saline & & & 0 & 0 & 0 \\
\hline 8 & 12 & Priming, C.P.E. & $0.6 \mathrm{mg} / \mathrm{kg}$ & C.P. $17 \alpha-20 \beta \mathbf{P}$ & & 6 norm. & & \\
\hline
\end{tabular}

*part.: partially ovulated; norm.: normally ovulated; sp.: spent.

${ }^{* *}$ Two fish were eliminated from data because ovarian biopsy showed more than $50 \%$ of oocytes to be atretic. 
stage 2: nucleus started peripheral migration, but still less than half way to the periphery;

stage 3: nucleus more than half way to the periphery;

stage 4: nucleus situated close to the micropile;

stage 5: matured oocyte (after germinal vesicle breakdown, before ovulation); stage 6 : follicles undergoing the process of resorption.

The proportion of the different stages was determined for each sample of 100 oocytes.

\section{Experiment 1}

Sixty fish transferred into experimental tanks on May 15th (transfer tI in Fig. 1) were divided into seven lots on May 23rd (day $0\left(D_{0}\right)$ of the experiment). Each lot was submitted to a different treatment as indicated in Table I. Lot 1 was treated by classical hypophysation with $6 \mathrm{mg} / \mathrm{kg}$ of C.P.E.; this dose was administered in two parts injected $24 \mathrm{~h}$ apart: firstly, priming on $D_{0}$ with one tenth of the total dose $(0.6 \mathrm{mg} / \mathrm{kg})$, followed on day $1\left(D_{1}\right)$ by the remainder of the dose $(5.4 \mathrm{mg} / \mathrm{kg})$. Lot 4 received the same "priming injection" of C.P.E. on $D_{0}$, but was treated with C.P. $17 \alpha-20 \beta$ P on $D_{1}$. Lots 2,3 , 5 and 6 received only one steroid injection on $\mathrm{D}_{0}$, without any gonadotropic priming. Lot 7 was a control, treated with physiological saline.

In this experiment, on $\mathrm{D}_{0}$ a blood sample and an ovarian sample were taken from each fish before any injection. Blood samples were then repeated every day until $D_{4}$, ovarian samples were taken from half of the fish on $D_{1}$, $D_{2}$ and $D_{3}$, and from all fish on $D_{4}$.

\section{Experiment 2}

Twelve fish were transferred into experimental tanks on May 26th (transfer tII in Fig. 1) to form lot 8 which is a repetition of the successful treatment 4 . In this experiment, the fish were submitted to daily ovarian samples on $\mathrm{D}_{0}, \mathrm{D}_{1}$ and $\mathrm{D}_{2}$ but no blood was sampled.

In both experiments, fish were checked every day for ovulation by manual pressure. Some fish gave a few ovulated oocytes (less than $1 \%$ of body weight) which can be considered as an abnormal ovulatory response; they were referred to as "partially ovulated fish". Fish which gave more than $3 \%$ of their body weight of ovulated oocytes were referred to as "normally ovulated fish". These fish were stripped for artificial insemination as soon as they had ovulated and referred to as "spent fish" in the table. Artificial insemination was performed by a classical method (se Meske et al., 1968) after equilibrating the temperature of the spawn to around $20-22^{\circ} \mathrm{C}$. The eggs were then incubated at $20-21^{\circ} \mathrm{C}$ in Zug bottles, and fertilization and hatching rates were checked. 


\section{RESULTS}

The ovulatory response of fish in the different lots is shown in Table I. Only lots 1, 4 and 8 responded to treatment. In lots 4 and 8, normal and clear-cut ovulations were observed, as a result of $17 \alpha-20 \beta \mathrm{P}$ treatment following C.P.E. priming: seven fish out of ten in lot 4 and six out of 12 in lot 8 gave ovulated oocytes which weighed between 3 and $15 \%$ of their body weight. After insemination, these eggs developed normally, showing fertilization rates of about $75-96 \%$ and hatching rates of about $70 \%$.

In contrast, responding fish from lot 1 (seven out of ten) showed a delayed response (on $\mathrm{D}_{3}$ and $\mathrm{D}_{4}$ ), giving few ovulated oocytes which were not tested for fertilization rates.

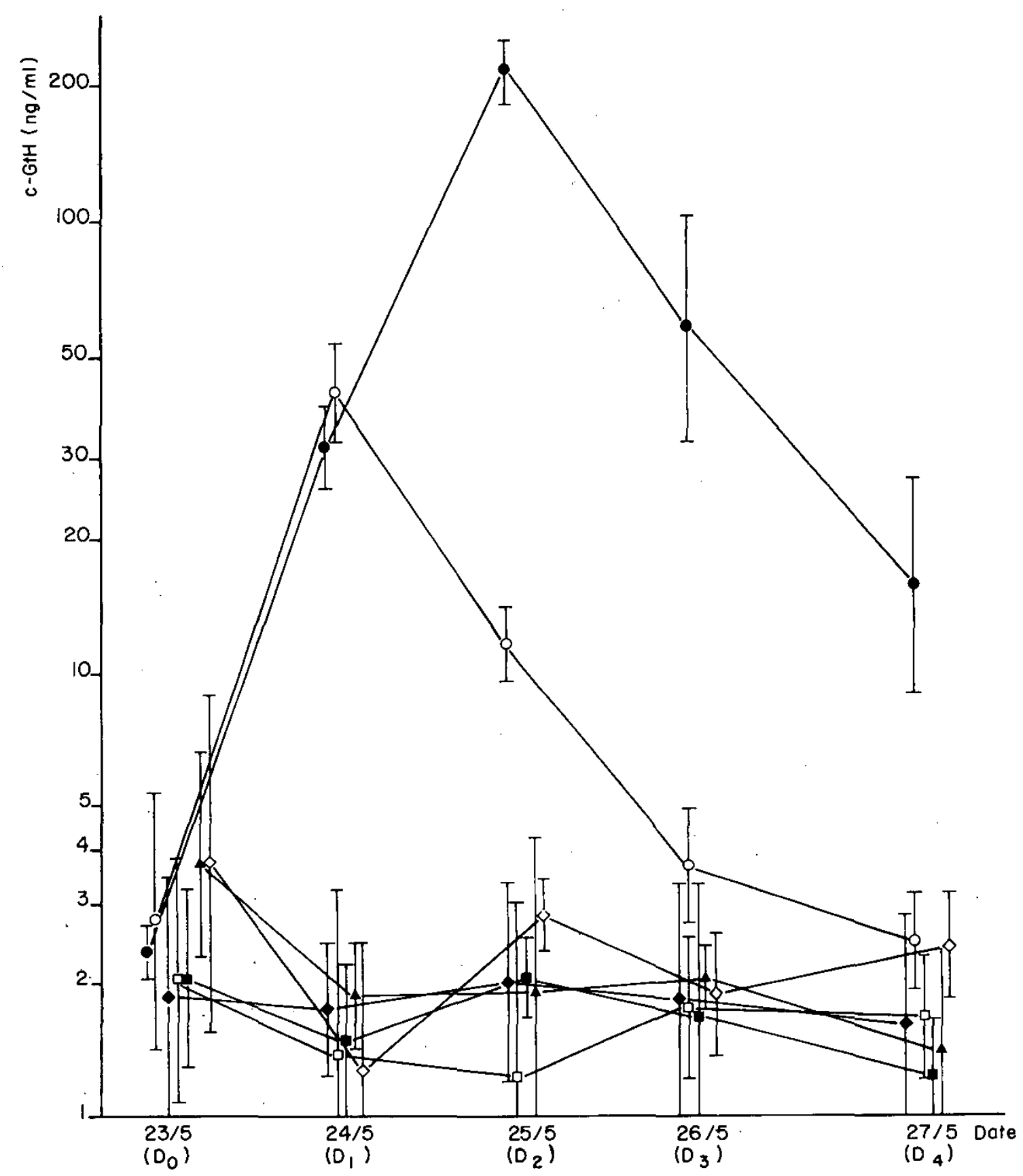

Fig. 2. Gonadotropin level (c-GtH) in blood of carp from different lots of experiment 1. 
The gonadotropin levels (c-GtH) in blood are presented in Fig. 2. In lots $2,3,5$ and 6 no significant changes occurred, compared to control (lot 7) or to basal levels on $D_{0}$, with values fluctuating around $2 \mathrm{ng} / \mathrm{ml}$. In lots 1 and 4 an increase can be observed on $D_{1}$ when c-GtH rose to $35 \mathrm{ng} / \mathrm{ml}$ following priming treatment; c-GtH in lot 4 began to decrease on $\mathrm{D}_{2}$ to reach the initial level on $\mathrm{D}_{4}$, whereas lot 1 showed a rise on $\mathrm{D}_{2}$ to $200 \mathrm{ng} / \mathrm{ml}, 24 \mathrm{~h}$ after the final hypophysation dose, followed by a decrease to $15 \mathrm{ng} / \mathrm{ml}$ on $\mathrm{D}_{4}$.

The proportions of oocytes at different stages are presented as graphs for each day and for each lot (Fig. $3 \mathrm{a}, \mathrm{b}$ and c). Before any treatment on $\mathrm{D}_{0}$, most oocytes were in stages 2 or 3 in every group. In controls (lot 7, Fig. $3 \mathrm{c}$ ) a higher proportion of resorbing oocytes (stage 6) was found on $\mathrm{D}_{0}$, com: pared to other lots; this may be related to the fact that these fish were the last to be caught during preparation of the experimental lots. This unexpected relationship introduces a small bias into the control group. Taking
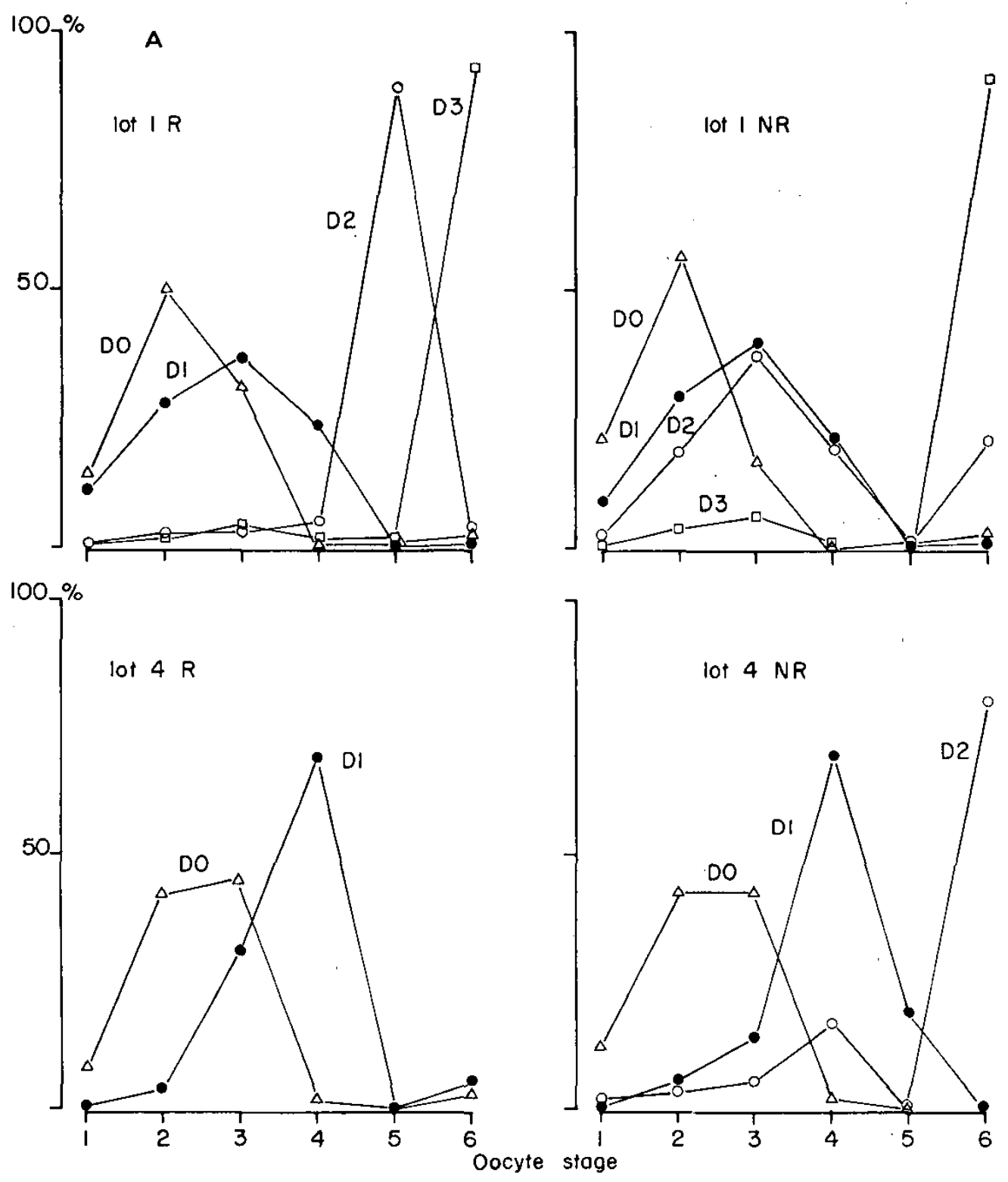

Fig. 3 a. Daily profiles of oocyte stages found by ovarian biopsy in lots 1 and 4 , divided into responding fish (i.e. ovulating) ( $2 R$ and $4 R$ ) and non-responding fish (NR). $\triangle \longrightarrow \triangle D_{0}$; $\bullet \longrightarrow \mathrm{D}_{1} ; \circ \longrightarrow \mathrm{D}_{2} ; \square \longrightarrow \mathrm{D}_{3} ; \backsim \mathrm{D}_{4}$. 

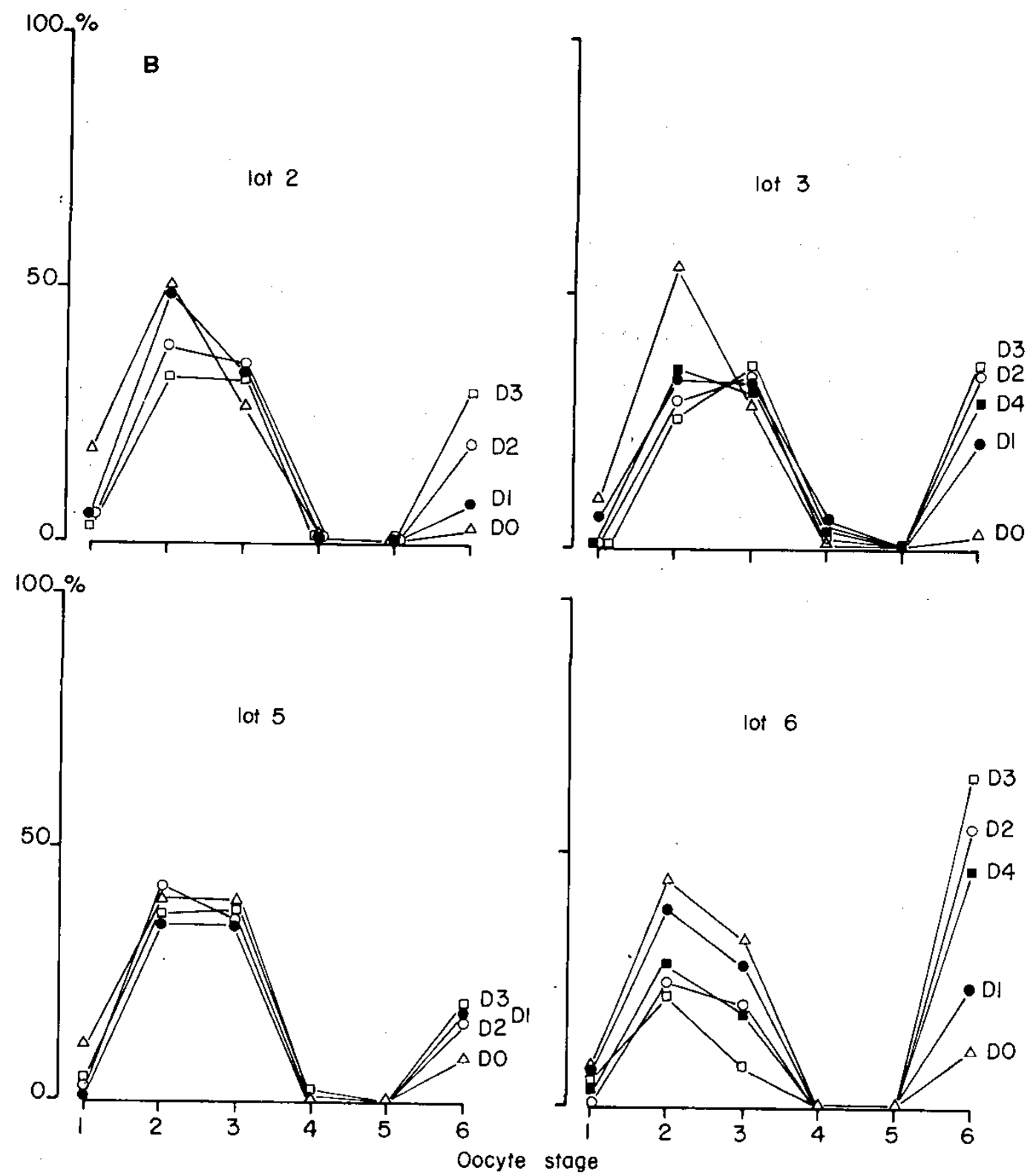

Fig. $3 \mathrm{~b}$. Daily profiles of oocyte stages found by ovarian biopsy in lots $2,3,5$ and 6 . (See Fig. 3 a for symbols.)

this fact into account, no significant change seems to occur in the mean stage of control oocytes from $\mathrm{D}_{0}$ to $\mathrm{D}_{4}$, except for a slight increase in resorbing oocytes. In lots $2,3,5$ and 6 no important changes are to be seen, though there was a decrease in the proportions of stages 2 and 3 and an increase in the proportion of stage 6 (resorbing oocytes); this phenomenon is particularly pronounced in lot 6 (D.O.C. treatment).

In order to understand the evolution of oocyte stages better, lots 1, 4 and 8 have been divided into responding (R) and non-responding (NR) groups according to ovulation response (even if partial as in lot 1) in Fig. 3 a and c. In every fish submitted to priming treatment, whether they ovulated $(R)$ or not (NR), the mode is displaced from stages $2-3$ on $\mathrm{D}_{0}$ to stages $3-4$ on $\mathrm{D}_{1}$. After the second treatment on $\mathrm{D}_{1}$, three possibilities are observed:

- When normal ovulation occurs following $17 \alpha-20 \beta$ P treatment on $D_{1}$ (lots $4 \mathrm{R}$ and $8 \mathrm{R}$ ), stage 5 cannot be seen because ovulation occurs before biopsy on $\mathrm{D}_{2}$. 


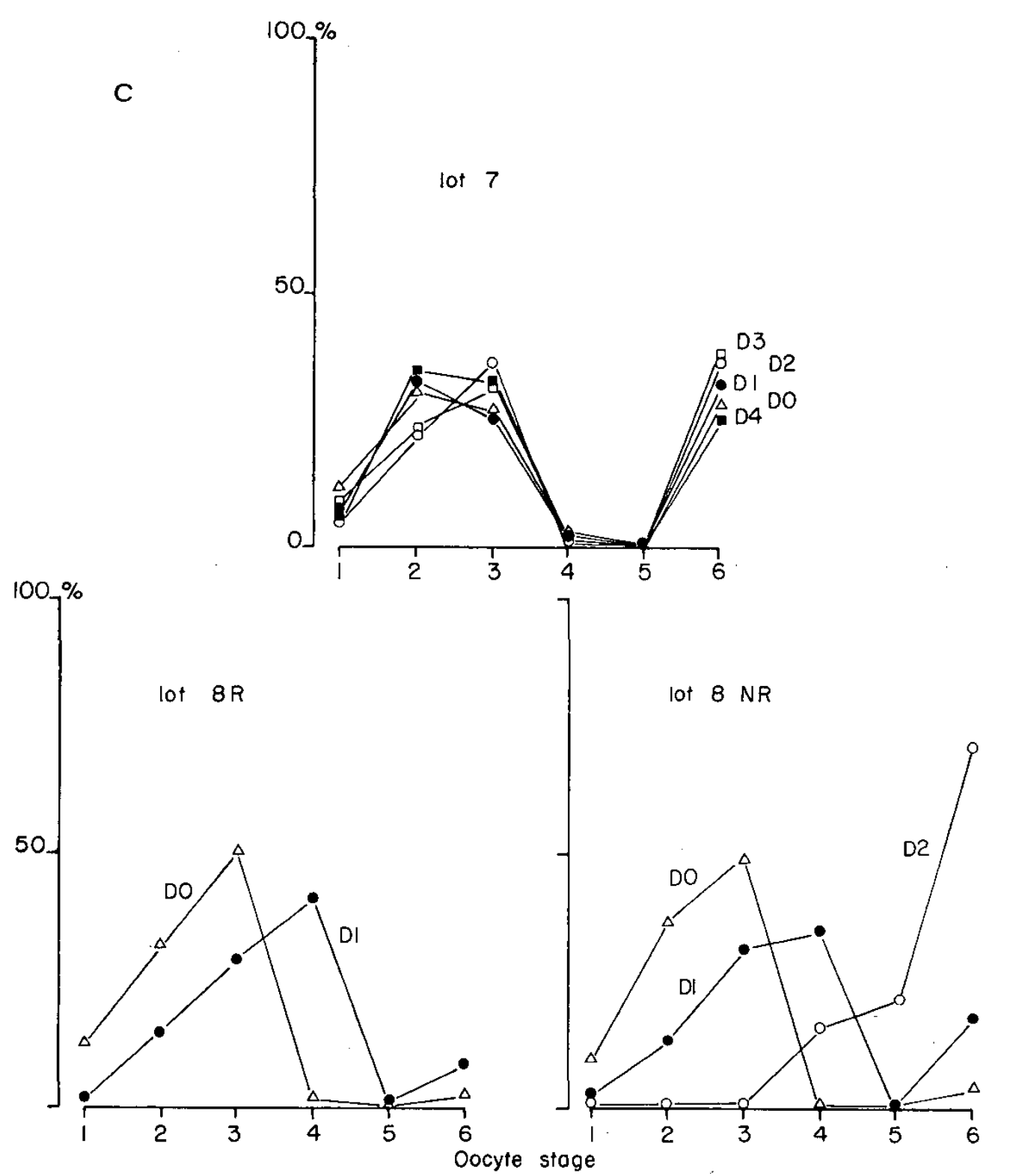

Fig. 3 c. Daily profiles of oocyte stages found by ovarian biopsy in lots 7 and 8 . (See Fig. 3 a for symbols.)

- When partial ovulation occurs following hypophysation (lot $1 \mathrm{R}$ ), it is preceded by a slower and abnormal process: the mode can be seen at stage 5 (mature) on $\mathrm{D}_{2}$, but only some mature oocytes ovulate and the others begin resorption on $\mathrm{D}_{3}$.

- In fish which did not respond to priming and hypophysation treatment, or to priming and C.P. $17 \alpha-20 \beta$ P treatment (lots $1 \mathrm{NR}, 4 \mathrm{NR}$ and $8 \mathrm{NR}$, Fig. 3 ) the common feature seems to be a direct change from stages 2,3 or 4 to resorption, without maturation (stage 5). No significant difference can be seen regarding the initial proportions of oocyte stages between responding and non-responding fish.

DISCUSSION

The most important fact reported here is the ability of a crude and cheap 
preparation of $17 \alpha-20 \beta \mathrm{P}$ to induce maturation and ovulation at a low temperature $\left(13-15^{\circ} \mathrm{C}\right)$ when administered 1 day after "priming" with a low dose of carp pituitary extract $(0.6 \mathrm{mg} / \mathrm{kg})$. At the same temperature, normal hypophysation following the same priming induces oocyte maturation followed by intrafollicular resorption instead of ovulation. The quality of the eggs was good, as shown by fertilization and eclosion data, compared to the irregular results usually observed at Zabieniec following normal hypophysation at $20^{\circ} \mathrm{C}$. This fact seems to favour the hypothesis of a slower ageing of gametes at low temperatures, and increases the interest in producing spawn in these conditions.

Whether or not $17 \alpha-20 \beta \mathrm{P}$ is the actual mediator normally produced by the ovary of carp in response to the gonadotropic stimulation of hypophysation is not proven; however, $17 \alpha-20 \beta \mathrm{P}$ has been shown to mimic the mediator's action in vitro in goldfish (Jalabert, 1976) which is closely related to carp, and the action is probably the same in carp. Thus the use of $17 \alpha-20 \beta \mathrm{P}$ instead of hypophysation by-passes one important step in the physiological process of maturation - ovulation induction, that is, the synthesis of the steroid mediator. The hypothesis that this step could be dependent on high temperatures $\left(>20^{\circ} \mathrm{C}\right)$ to proceed normally, whereas the following step, oocyte maturation and ovulation triggered by $17 \alpha-20 \beta$ P, could occur normally at lower temperatures (around $13^{\circ} \mathrm{C}$ ), seems to explain the fact that $17 \alpha-20 \beta \mathrm{P}$ is more efficient in the present experiment than a high dose of C.P.E.

Another important point in the present data is the fact that $17 \alpha-20 \beta \mathrm{P}$, pure or not, alone or in association with D.O.C., is unable to induce maturation and ovulation if administered without prior priming with a low dose of C.P.E. This priming induces a change of oocyte from stages $2-3$ to $3-4$ which represents, in fact, the migration of the germinal vesicle towards a more peripheral position. The peripheral position of the germinal vesicle appears, therefore, to be a necessary condition for the successful action of $17 \alpha-20 \beta \mathrm{P}$ in vivo in carp, as it is for the action of $17 \alpha-20 \beta$ in vivo in trout (Jalabert et al., 1976) and in vitro in trout (Jalabert et al., 1972), in goldfish (Jalabert et al., 1973) and in northern pike (Jalabert, 1976). "Priming" can be defined here as the treatment which induces germinal vesicle migration as a correlative phenomenon with the acquisition of oocyte responsiveness to $17 \alpha-20 \beta \mathrm{P}$.

The problem that remains is to know by which mechanism a crude pituitary extract acts to perform this "priming". The radio-immunoassay for c-GtH shows an increase in the plasma concentration from about 2 to 35 $\mathrm{ng} / \mathrm{ml} 24 \mathrm{~h}$ after injection of the low priming dose of C.P.E. $(0.6 \mathrm{mg} / \mathrm{kg})$; but until the same priming effect is proven to be brought about by the injection of an amount of pure c-GtH giving a similar rise in plasma level of c-GtH, the possible involvement of any other pituitary hormone cannot be excluded. Whatever the pituitary hormone responsible for priming is, it appears from the present data that its action is probably mediated neither by $17 \alpha-20 \beta \mathrm{P}$, 
nor by D.O.C. which are ineffective in transforming the oocytes from stages $2-3$ to stages $3-4$.

Some fish appear not to respond at all to either priming and hypophysation treatment (lot $1 \mathrm{NR}$, three fish out of ten) or priming and 17 $\alpha-20 \beta \mathrm{P}$ treatment (lot $4 \mathrm{NR}$, three fish out of ten; lot $8 \mathrm{NR}$, six fish out of 12). In these fish, which cannot be distinguished from the others regarding initial oocyte stage, the effect of priming seems to be the same as in responding fish, but subsequent treatment by hypophysation (lot $1 \mathrm{NR}$ ) or with $17 \alpha-20 \beta \mathrm{P}$ (lots $4 \mathrm{NR}$ and $8 \mathrm{NR}$ ) results in increased resorption without maturation. In other words, the morphological consequence of "priming" (germinal vesicle migration) seems to be dissociated here from the physiological characteristic of responsiveness to $17 \alpha-20 \beta$ P. A simple hypothesis could be either that the dose of the second treatment was not appropriate to these fish, or that degenerative changes were already in progress, even if not apparent. The latter may be the more likely hypothesis: from the first day of the experiment, the fish were submitted every day to capture, anaesthesia, blood sampling and ovarian biopsy and the stress resulting from this severe handling could be responsible for the lack of response observed in some fish.

In the experimental plan chosen here, $17 \alpha-20 \beta$ P was the only steroid (although an impure preparation) used after priming, as it was logically supposed to offer the best opportunity for a successful response, because of its in vitro efficiency in goldfish oocyte maturation (Jalabert, 1976). Nevertheless, it is possible that other related steroids may act to give the same result after hypophysial priming. For instance, progesterone at very high doses was shown to produce some ovulations in the loach Misgurnus fossilis (Kirshenblat, 1952), in goldfish (Yamazaki, 1965) and in mullet (Cassifour and Chambolle, 1975).

The present work on carp opens new perspectives in current practice with (1) the possibility to replace the classical hypophysation method by a sequential treatment - priming treatment with a low dose of carp pituitary extract followed by a treatment with a cheap steroid hormone (instead of the expensive high dose of pituitary extract); (2) the possibility of inducing carp to spawn at low temperature $\left(13-15^{\circ} \mathrm{C}\right)$ and produce eggs of high quality, saving the energy which is needed to heat the water for spawners to $20^{\circ} \mathrm{C}$ in classical hypophysation.

\section{ACKNOWLEDGEMENTS}

The realization of this work was made possible by an exchange and cooperation programme between I.N.R.A. (France) and the Ministry of Agriculture (Poland).

A part of this work (radio-immunoassays, steroid synthesis) was supported by C.N.R.S. (A.T.P. no. 2104, Ecophysiologie comparée).

We are very grateful to all the personnel of Zabieniec station who, with great skill, helped us to realize this work, and particularly to Z. Okoniewski, S. Danielewski, S. Wojdak, A. Grelka, H. Korczak and E. Danielewska. 


\section{REFERENCES}

Bieniarz, K. and Epler, P., 1976. Preliminary results on the in vivo studies on the ovarian resorption in Carp Cyprinus carpio. J. Fish Biol., 8: 449-451.

Breton, B., Billard, R., Jalabert, B. and Kann, G., 1972. Dosage radioimmunologique des gonadotropines plasmatiques chez Carassius auratus au cours du nycthémère et pendant l'ovulation. Gen. Comp. Endocrinol., 18: 463-468.

Brzuska, E. and Bieniarz, K., 1977. The in vivo studies of carp oocytes. In press.

Cassifour, P. and Chambolle, P., 1975. Induction de la ponte par injection de progestérone chez Crenilmugil labrasus, Poisson Téléostéen, en milieu saumâtre. J. Physiol. (Paris), 70: 565-570.

Fostier, A., Jalabert; B. and Terqui, M., 1973. Action prédominante d'un dérivé hydroxylé de la progestérone sur la maturation in vitro des ovocytes de la Truite Arc-en-ciel Salmo gairdneri. C.R. Acad. Sci., 277: 421-424.

Houssay, B.A., 1931. Action sexuelle de l'hypophyse sur les poissons et les reptiles. C.P. Soc. Biol., 106: 377-378.

Jalabert, B., 1976. In vitro oocyte maturation and ovulation in rainbow trout (Salmo gairdneri), northern pike (Esox lucius) and goldfish (Carassius auratus). J. Fish. Res. Board Can., 33: 974-988.

Jalabert, B., Bry, C. and Breton, B., 1972. Maturation et ovulation in vitro des ovocytes de la Truite Arc-en-ciel Salmo gairdneri. C.R. Acad. Sci., 275: 1139-1142.

Jalabert, B., Bry, C., Szöllösi, D.and Fostier, A., 1973. Etude comparée de l'action des hormones hypophysaires et stéroïdes, sur la maturation in vitro des ovocytes de la Truite et du Carassin. Ann. Biol. Anim. Biochim. Biophys., 13 (hors série): 59-72.

Jalabert, B., Bry, C., Breton, B. and Campbell, C., 1976. Action de la $17 \alpha$ hydroxy-20 $\beta$ dihydroprogestérone et de la progestérone sur la maturation et l'ovulation in vivo et sur le niveau d'hormone gonadotrope plasmatique t-GtH chez la Truite Arc-en-ciel Salmo gairdneri. C.R. Acad. Sci., 281: 811-814.

Kirshenblat, T.D., 1952. The action of steroid hormones on female loach. Dokl. Akad. Nauk. S.S.S.R., 83: 629-632.

Meske, C.H., Woynarovich, E., Kausch, H., Lühr, B. and Szablewski, W., 1968. Hypophysierung von Aquarienkarpfen und künstliche Laichbrütung als Methode zur Züchtung neuer Karpfrassen. Theor. Appl. Genet., 38: 47-51.

Norymberski, J.K. and Woods, G.F., 1955. Partial reduction of steroid hormones and related substances. J. Chem. Soc., 1955: 3426-3430.

Schuetz, A.W., 1974. Role of hormones in oocyte maturation. Biol. Reprod., 10: 150178.

Smith, L.L., Marx, M., Mendelsohn, H., Foellt, T. and Goodman, J.J., 1962. 16 $\alpha$ hydroxysteroids XII -21 amino derivatives of $9 \alpha$ fluorohydrocortisone, J. Am. Chem. Soc., 84: $1265-1270$.

Vinogradov, V.K., 1966. Techniques of rearing phytophageous fishes. FAO World Symp. Warm Water Pond Fish Culture. FAO, Rome, May 1966.

Yamazaki, F., 1965. Endocrinological studies on the reproduction of the female goldfish, Carassius auratus L., with special references to the function of the pituitary gland. Mem. Fac. Fish. Hokkaido Univ., 13: 1-65. 